única observação é a tradução do misterioso HMOD que o autor não dá (ou eu não encontrei) - HMOD = hora mão-de-obra direta;

b) recusa de entrar na discussão entre custeio direto e por absorção - mostrando o mesmo exemplo pelos dois métodos, mas mantendo-se neutro; c) apresentação do rateio entre muitos produtos sem complicações demasiadas, e conseqüente fixação de preços;

d) introdução do lucro-objetivo na fixação do preço.

As fraquezas são oriundas todas de uma super-simplificação de certos problemas. Além disso, como já foi dito, o tltulo nacional deixa fora o "para o executivo financeiro", dando. conseqüentemente, a impressão de tratar-se de uma teoria geral de preços, em lugar de uma correlação custo-preço.

O livro está cheio de casos, todos norte-americanos, que são todos financeiros. $O$ autor ignora, ao citar a Dupont, que ela manteve para fixação de preços um grupo que fazía árvores de decisão para ver o retorno. Mas cita a diferença entre a Dupont e outras empresas. Portanto, pode ser dito sem delongas que este livro deveria ilustrar todos os executivos superintendentes e financeiros das empresas brasileiras e multinacionais, tornando-os cientes dos problemas do binômio custo-preço. Como livro de leitura, deve acompanhar cursos superiores 〈pós-graduados de mercadologia, administração de custos e da produção etc.).

A obra deve ser acompanhada de um bom livro de casos no ensino. Isso se demonstra pelo fato que nada melhor do que forçar um aluno a fixar seu preço e correlacionar todos os elementos que devem ser levados em conta.

Excelente apresentação gráfica, boa tradução, clareza contábil tudo satisfatório para o ușário.

Kurt Ernst Weil.

\footnotetext{
* Professer no Departamento de Administração da Produção e de Operações Indus. triais, da EAESP/FGV.
}

Schumacher, E. F. O negócio é ser pequeno, 2. ed. Trad. Otávio Alves Velho. Rio de Janeiro, Zahar, 1979. O título do original desta obra, em inglês, é Small is Beautiful. A tradução em língua portuguesa é baseada na $6 .^{a}$ reimpressão, publicada em 1976, por Blond \& Briggs, de Londres.

O negócio é ser pequeno consiste numa coleção de artigos escritos e de conferências proferidas pelo autor entre 1964 e 1977, ano do seu falecimento. Alguns capítulos inéditos foram acrescentados, para ajudar a compor um todo orgânico desta coleção de ensaios, que nos permite obter uma clara noção do pensamento básico do autor, economista, professor. e presidente da Junta Nacional de Carvão da Grã-Bretanha de 1950 a 1970.

Desde seu aparecimento, em 1973, esta apologia da pequenez constituiu-se em grande.êxito junto à crescente legião dos que se inquietam pelo futuro da economia e das instituições humanas.

Os problemas que Schumacher aborda abrangem extensa gama de questões de aguda atualidade, ainda mais para os países menos desenvolvidos:

- ecologia e combate à poluição, sob todas as suas formas;

- preservação dos recursos naturais; - alternativas energéticas, esgotamento de combustíveis fósseis, ameaças dá energia nuclear e do lixo atômico;

- transferência de tecnologia aos países do Terceiro Mundo; escolha da tecnologia adequada para os países em desenvolvimento; uso de tecnologia intermediária, em oposição à tecnologia requintada, como sendo mais apropriada para os países menos avançados;

- desenvolvimento regional rural, a fim de combater a excessiva urbanização e a proliferação de favelas em volta das megalópoles;

- aumento da eficiência da ajuda aos países pobres, para que se evite os desapontamentos verificados na década de $70 \mathrm{com}$ a pouca eficiência desse auxílio;

- criação de pequenas e médias empresas, revertendo-se a tendência de desumanização do trabalhador, característica da grande indústria;

- educação, única fórmula para se controlar a explosão populacional, causa da pobreza que se alastra na maior parte do mundo.

$\mathrm{O}$ autor compartilhava a inquietação dos membros do Clube de Roma e do Grupo de Dinâmica de Sistema do Massachusetts Institute of Technology, que, na mesma época, se dedicavam aos problemas de explosão populacional e esgotamento de recursos naturais. Schumacher, entretanto, não perece apreciar modelos matemáticos. Acha desnecessário usar computadores e simulação para concluir que "não há crescimento infinito num mundo de recursos finitos" e que, portanto, devemos procurar equilíbrio e limitar o crescimento.

Schumacher esmera-se em desmascarar o "culto obsessivo do crescimento econômico ilimitado" e também o próprio mito do desenvolvimento econômico forçado por meio de industrialização.

As recomendações centrais do autor, para os países menos desenvolvidos, são contidas em quatro proposições, que transcrevemos:

1. Têm de ser criadas indústrias nas áreas onde as pessoas vivem agora $\mathrm{e}$ não, primordialmente, em regiões metropolitanas para as quais tendem a migrar.

2. Essas indústrias têm de ser, em média, suficientemente baratas para que possam ser criadas em grande quantidade sem exigir um nível inatingível de formação de capital e de importações.

3. Os métodos de produção empregados devem ser relativamente sim. ples, de sorte que a demanda de. grandes qualificações seja minimizada, não apenas no processo de produção, mas também em matérias de organização, fornecimento de matérias-primas, financiamento e comercialização. 
4. A produção deve ser, sobretudo, dependente de materiais locais e destinada ao consumo local.

Estes quatro requisitos só podem ser satisfeitos se houver um enfoque regional de desenvolvimento $e$, mais ainda, se houver um esforço consciente para criar e.aplicar o que se pode denominar uma "tecnologia intermédia".

Para os países industrializados, o autor propõe como missão fundamental alcançar a pequenez dentro da organização grande, "de modo que cada pessoa possa abarcála na mente e imaginação".

Ser pequeno, observa Schumacher no epílogo do seu livro, é praticar quatro virtudes cardinais: prudência, jüstiça, fortitude e temperança.

Assim, talvez, o homem poderá construir um sistema de produção que não violente a natureza e um tipo de sociedade que não mutile o homem, cerne do pensamento do autor.

\section{Claude Machline*}

\footnotetext{
* Professor no Departamento de Administração da Produção e de Operações Industriais, da EAESP/FGV.
}

Faria, A. Nogueira de. Organizacão e métodos. Rio de Janeiro, Livros Técnicos e Científicos, 1982. 216 p. Brochura, sumário, índice remissivo, glossário, bibliografia, ilustrado.

Permito-me começar a resenha com a definição do objetivo do livro, extrarda do prefácio: "destinado a univer sitários - aumento de produtividade lógica (cartesiana) - tempos e movimentos - carga horária de 60 horas - administração, engenharia e economia".

Assim, em palavras-chave é possível ver para onde quer ir e como o autor deseja chegar aos fatos por meio dessa obra. Ele quer permitir que o jovem universitário raciocine dentro da lógica chegando a soluções de métodos de trabalho. O livro chega a atingir plenamente essa meta do autor. Tive uma vez a oportunidade de definir a administração por objetivos: "compra de um tailleur por uma mulher gorda que procura caber dentro por meio de dieta." Da mesma maneíra, o autor consegulu colocar dentro de poucas páginas uma figura da mulher gorda, a saber, a ciêncía de organização e métodos, atingindo bem o objetivo. Parabéns, portanto. O que foi cortado, o que está extensamente tratado é escolha do autor quem quiser mais procure o livro do mesmo autor Organização de empresas.

O livro comeca com o seguinte sumário: 1. Função de organização e métodos; 2 "Técnicas de levantamento; 3. Anállse do trabalho; 4. Racionalização e simplificação do trabalho; 5. Os métodos de trabalho; 6. Os postos de trabalho e a ambiência; 7 . Os centros de produção.

Ao resenhar o primeiro capítulo, devo considerá-lo claro e bem explicito, ressalvando o direito de criticar certos aspectos, a saber: o autor coloca "posição correta de $O$ \& $M$ no organograma" na figura 1.1, dando a impressão ao.incauto aluno de que esta é a única posição. Pelo organograma parece que a diretoria colegia- da é responsável e manda na presidência, que manda na superintendência - sistema GM, de difícil aplicação em certas empresas brasileiras. A figura 1.2 parece-me ser de empresa muito grande, portanto, "modelo completo". As definições de eficácia, eficiência e produtividade no glossário estão certas, só que de mais difícil memorização que incisivas generalizacões, tendo em vista o fim didático do livro. A bibliografia do capítulo em português é muito boa.

O capítulo 2 é um primor, mostrando o profundo conhecimento do autor no ássunto. Posso não estar de acordo com certas perguntas do questionário apresentado, mas este é completo - quem não gostar de algo, pode cortá-lo. Também se nota no autor a vontade de evitar os métodos Dasp de administração pública como procedimentos exclusivos que levam ao resultado. Fiz uma experiência, aplicando integralmente o referido método, e o resultado foi muito bom. A aplicação é demorada, mas talvez seja isso exatamente o que o técnico deseja, em 1982, ano de dificuldades generalizadas. Agora, quem óbservar que o resultado da "tabulação" (ver glossário) pode dar em algo diferente do esperado - o mesmo questionário pode dar origem a duas interpretações na tabulação; donde, me permito acrescentar que são necessárias indicações na pesquisa de opinião, como o autor quer fazer para a correlação de certas perguntas, para identificar o significado da resposta. Mas, antes de tudo, o capítulo permite trabalhar dentro de regras que levam a resultados úteis, portanto, é excelente.

No terceira capítulo - Análise do trabalho - temos um bom resumo, faltando uma "divisão do trabalho" em processos, operações, elementos etc., antes de entrar em therbligs, e uma definição bivalente de operação e processo no glossário. Quem precisar, que recorra à bibliografia do capítulo, que dá indicações suficientes. Como engenheiro defino operação como "parte de processo, existente em muitos processos, tanto burocráticos quanto industriais, por exem"plo, 'contabilização" ou 'usinagem'" 